Click www.researchjournal.co.in/online/subdetail.html to purchase.

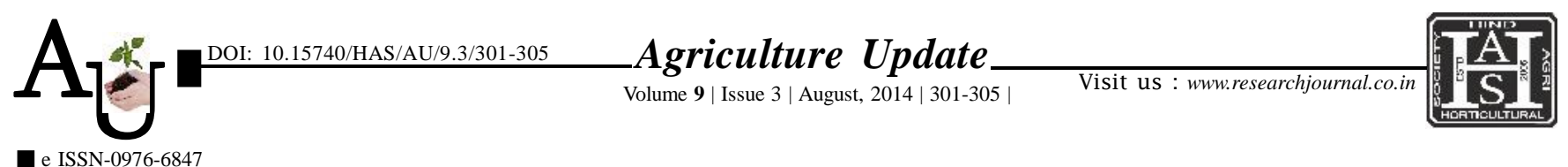

Research Article

\title{
Yield attributes and yield of fenugreek (Trigonella foenum graecum L.) under different levels of phosphorus, molybdenum and inoculation of PSB
}

\author{
SHWETA SHARMA, YOGESH SHARMA AND C.M. BALAI
}

Article Chronicle: Received :

18.04.2014;

Revised :

25.05.2014;

Accepted :

12.06.2014

KEY WoRds:

Fenugreek, Interaction, Molybdenum, Nodules, Phosphorus, Protein, PSB, Yield
SummarY : A field experiment was conducted at Agronomy farm, College of Agriculture, Bikaner during Rabi season, 2010-11 on loamy sand soil to investigate the effect of phosphorus $\left(0,20,40\right.$ and $60 \mathrm{~kg} \mathrm{P}_{2} \mathrm{O}_{5}$ ha $\left.^{-1}\right)$, molybdenum $\left(0.0,0.5\right.$ and $\left.1.0 \mathrm{~kg} \mathrm{Mo} \mathrm{ha}^{-1}\right)$ and PSB (without inoculation and with inoculation) on yield attributes, yield and seed quality of fenugreek (Trigonella foenum graecum L.). The application of phosphorus upto $40 \mathrm{~kg}_{2} \mathrm{O}_{5}$ ha $^{-1}$ resulted in significantly higher number of branches per plant, chlorophyll content at flowering stage, nodules per plant, pods per plant, seeds per pod, seed and straw yield over their respective preceding levels $\left(0\right.$ and $20 \mathrm{P}_{2} \mathrm{O}_{5}$ ha $\left.^{-1}\right)$ but it was found at par with $60 \mathrm{~kg} \mathrm{P}_{2} \mathrm{O}_{5} \mathrm{ha}^{-1}$ in respect to branches per plant, chlorophyll content at flowering stage, nodules per plant, pods per plant, seeds per pod, seed and straw yield of fenugreek. Among different levels of molybdenum, 0.5 $\mathrm{kg} \mathrm{Mo} \mathrm{ha}^{-1}$ gave significantly higher branches per plant, chlorophyll content at flowering stage, nodules per plant, pods per plant, seeds per pod, seed and straw yield over respective lower level. PSB inoculation significantly enhanced the branches per plant, chlorophyll content at flowering stage, nodules per plant, pods per plant, seeds per pod, seed and straw yield of fenugreek. The test weight increased with the successive levels of applied phosphorus, molybdenum and PSB inoculation but difference could not reach the level of significance. The interaction effect of phosphorus $\times$ PSB was found significantly higher branches per plant, pod per plant and seed yield $\left(1568 \mathrm{~kg} \mathrm{ha}^{-1}\right)$ recorded with treatment combination $40 \mathrm{~kg} \mathrm{P}_{2} \mathrm{O}_{5} \mathrm{ha}^{-1}+$ with inoculation of PSB which was at par with other treatment combination $60 \mathrm{~kg} \mathrm{P}_{2} \mathrm{O}_{5}$ ha $^{-1}+$ with inoculation of PSB.

How to cite this article : Sharma, Shweta, Sharma, Yogesh and Balai, C.M. (2014). Yield attributes and yield of fenugreek (Trigonella foenum graecum L.) under different levels of phosphorus, molybdenum and inoculation of PSB. Agric. Update, 9(3): 301-305.
Author for correspondence :

\section{C.M.BALAI}

Krishi Vigyan Kendra, (MPUAT) DUNGARPUR, (RAJASTHAN) INDIA

Email:cmmpuat@

gmail.com,cmpuat@ gmail.com

See end of the article for authors' affiliations 